CLINICAL STUDY

\title{
Circulating levels of ghrelin in human fetuses
}

Donatella Cortelazzi, Vincenzo Cappiello, Paola S Morpurgo, Stefania Ronzoni ${ }^{1}$, Maria S Nobile De Santis ${ }^{1}$, Irene Cetin ${ }^{1}$, Paolo Beck-Peccoz and Anna Spada

Institute of Endocrine Sciences, Ospedale Maggiore IRCCS and ${ }^{1}$ Department of Obstetrics and Gynecology, DMCO Ospedale San Paolo, University of Milan, Milano, Italy

(Correspondence should be addressed to Anna Spada, Institute of Endocrine Sciences, University of Milan, Pad. Granelli, Ospedale Maggiore IRCCS, Via F. Sforza 35, 20122 Milan, Italy; Email: anna.spada@unimi.it)

\begin{abstract}
Objective: Ghrelin is a GH secretagog isolated recently from rat stomach and involved in the stimulation of food intake and adiposity in rodents and humans. Moreover, subsequent studies showed that ghrelin is expressed in rat and human placenta, suggesting a possible influence of the peptide on fetal growth. The aim of this study was to evaluate circulating levels of ghrelin in appropriate for gestational age (AGA) or intrauterine growth-restricted (IUGR) fetuses.

Subjects and methods: Ghrelin levels between 20 and 39 weeks of gestation were measured in 16 AGA and nine IUGR fetuses in whom blood was collected by cordocentesis performed for prenatal diagnosis of different diseases or during elective cesarean section. In most samples, GH, cortisol and leptin levels were also evaluated. Results are expressed as means \pm S.D. Differences were tested using the Student's $t$-test with Welch correction. $P<0.05$ was considered significant.

Results: All fetuses showed levels of ghrelin in the umbilical venous blood $(100 \pm 99 \mathrm{pmol} / \mathrm{l})$ that did not correlate with the gestational age or the maternal ghrelin levels. No difference was found between umbilical venous and arterial concentrations, suggesting that fetal tissues are a source of ghrelin. Ghrelin levels in IUGR fetuses were significantly higher than those found in AGA fetuses $(176 \pm 125$ vs $58 \pm 44 \mathrm{pmol} / \mathrm{l} ; \mathrm{P}<0.005)$. Moreover, in samples obtained at birth, ghrelin concentrations correlated negatively with birth weight $(P<0.05)$. In IUGR fetuses, GH and cortisol concentrations were higher and leptin levels lower than in AGA fetuses, although no significant correlation between these parameters and ghrelin levels was found.

Conclusion: The presence of ghrelin in the fetal circulation as well as its increase in IUGR fetuses suggest a role of this peptide during intrauterine development.
\end{abstract}

European Journal of Endocrinology 149 111-116

\section{Introduction}

Ghrelin is an acylated peptide recently isolated from the rat stomach that exerts a wide range of metabolic functions $(1-6)$. This peptide stimulates the secretion of growth hormone $(\mathrm{GH})$ and other pituitary hormones such as adrenocorticotropin (ACTH) and prolactin (PRL), probably by acting at both hypothalamic and pituitary levels (7-9). Moreover, ghrelin is an important regulator of energy balance since it has been demonstrated to increase food intake in rodents and humans $(6,10,11)$. Accordingly, circulating ghrelin levels are influenced by acute and chronic changes in nutritional state $(11-15)$.

As far as the sources of ghrelin are concerned, previous studies showed that this peptide is produced predominantly by the stomach, whereas substantially lower amounts are derived from the bowel, pituitary, hypothalamus, kidney and placenta $(1,5,13,16)$.
The demonstration that ghrelin is expressed in the rat and human placenta is consistent with the notion that this organ is able to synthesize a variety of hormones, including several members of the somatotrophic axis, such as GH, GH-releasing hormone (GHRH), insulin-like growth factor-I (IGF-I) and somatostatin. The pregnancy-related time course of ghrelin expression observed in the placenta together with the recently reported presence of ghrelin in fullterm neonates' cord samples suggest that this peptide might influence fetal growth during intrauterine development $(16,17)$. However, data on the presence of ghrelin in the fetal circulation before delivery are presently unavailable.

The aim of this study was to evaluate circulating levels of ghrelin in appropriate for gestational age (AGA) or intrauterine growth-restricted (IUGR) fetuses and its relationships with fetal $\mathrm{GH}$, cortisol and leptin levels. 


\section{Materials and methods}

\section{Subjects}

Twenty-five pregnancies between 20 and 39 weeks of gestation were studied in the Department of Obstetrics and Gynecology of the San Paolo Hospital, Milan (Table 1). The study included eight women carrying AGA fetuses (four females and four males) requiring fetal blood sampling for prenatal diagnosis of different disorders (chromosomal abnormalities, maternal infections, thrombocytopenia) that were subsequently excluded and nine pregnancies carrying fetuses (four females and five males) with intrauterine growth restriction, as documented by measurements of abdominal circumferences below the tenth percentile of reference values at ultrasound examination (18). Growth restriction was confirmed at birth as the neonatal weight below the tenth percentile according to Italian standards for birth weight and gestational age (19) (Table 1). In IUGR fetuses, samples were collected either by cordocentesis performed for rapid karyotyping and biochemical assessment as part of our routine clinical protocol (20), or at the time of cesarean section performed in the interest of the fetus. Finally, eight AGA fetuses (three females and five males) were studied at the time of cesarean section performed between the 37 th and the 39th week of gestation for maternal indications. The protocol was approved by the San Paolo Institute Board. All pregnant women gave their informed consent to both cordocentesis and hormone measurements.

\section{Samples}

Maternal and fetal blood samples were collected simultaneously after an overnight fast. Fetal blood was obtained by direct puncture of the umbilical vein as previously described (19), either in utero or during elective cesarean section. At cesarean section umbilical arterial and venous blood samples were withdrawn from a doubly clamped segment of the cord immediately after fetal extraction. None of the babies showed signs of distress at delivery. The reliability of fetal sampling was assessed by red cell volume analysis with a Coulter counter and confirmed by Kleihauer smears, as previously reported (19).

\section{Assay}

Fetal and maternal plasma samples for ghrelin analysis were stored in ice-chilled EDTA/aprotinin polypropylene tubes, immediately separated by centrifugation at 3000 r.p.m. for $10 \mathrm{~min}$ at $4{ }^{\circ} \mathrm{C}$ and stored at $-80{ }^{\circ} \mathrm{C}$ until assay. In agreement with previous reports $(13,21)$, we did not observe differences between control samples assessed with or without extraction procedures (data not shown). Therefore, due to the small amounts of fetal plasma available for hormone measurements, the assay was used without an extraction procedure. Plasma ghrelin was measured in one run with a commercial RIA kit (Phoenix Pharmaceuticals Inc., Belmont, CA, USA) that uses a polyclonal antibody recognizing the C-terminal end of ghrelin, i.e. total ghrelin. The detection limit was $9 \mathrm{pmol} / \mathrm{l}$. Intra- and interassay CVs were $6 \%$ and $14 \%$ respectively.

Plasma leptin levels were measured by enzyme-linked immunosorbent assay (DRG Instruments, GMBH, Germany), and GH and cortisol by immunofluorometric assay (AutoDelfia kit, Perkin-Elmer Lifesciences, Turku, Finland).

\section{Statistics}

The results are expressed as means \pm S.D. Differences between groups were tested using the Student's $t$-test with Welch correction and correlations were examined by linear regression analysis. A $P$ value $<0.05$ was considered significant.

\section{Results}

All fetuses included in the study showed detectable levels of ghrelin in the umbilical venous blood that were highly variable $(100 \pm 99 \mathrm{pmol} / \mathrm{l}$; range

Table 1 Fetal characteristics at the time of the sampling and at the time of delivery. All data are presented as means \pm S.D. $n=$ number of cases.

\begin{tabular}{|c|c|c|c|c|c|c|}
\hline & \multicolumn{4}{|c|}{ Sampling } & & \\
\hline & \multicolumn{2}{|c|}{ Cordocentesis } & \multicolumn{2}{|c|}{ Cesarean section } & \multicolumn{2}{|c|}{ Delivery } \\
\hline & $\begin{array}{l}\text { Gestational age } \\
\text { (weeks) }\end{array}$ & $\begin{array}{l}\text { Gender } \\
\text { M/F }\end{array}$ & $\begin{array}{l}\text { Gestational age } \\
\text { (weeks) }\end{array}$ & $\begin{array}{l}\text { Gender } \\
\mathrm{M} / \mathrm{F}\end{array}$ & $\begin{array}{l}\text { Fetal weight } \\
\text { (g) }\end{array}$ & $\begin{array}{c}\text { Gestational age } \\
\text { (weeks) }\end{array}$ \\
\hline AGA fetuses, $n=16$ & $\begin{array}{c}25.8 \pm 4.2 \\
n=8\end{array}$ & $4 / 4$ & $\begin{array}{c}37.8 \pm 0.8 \\
n=8\end{array}$ & $5 / 3$ & $3114 \pm 424$ & $38.2 \pm 1.2$ \\
\hline IUGR fetuses, $n=9$ & $\begin{array}{c}27.2 \pm 1.5 \\
n=4\end{array}$ & $4 / 0$ & $\begin{array}{c}34.5 \pm 2.8 \\
n=5\end{array}$ & $1 / 4$ & $1221 \pm 634$ ** & $31.6 \pm 3.4^{*}$ \\
\hline
\end{tabular}

${ }^{\star} P<0.01$ vs normal (see ref. 19$),{ }^{\star \star} P<0.001$ vs normal (see ref. 19$)$. 

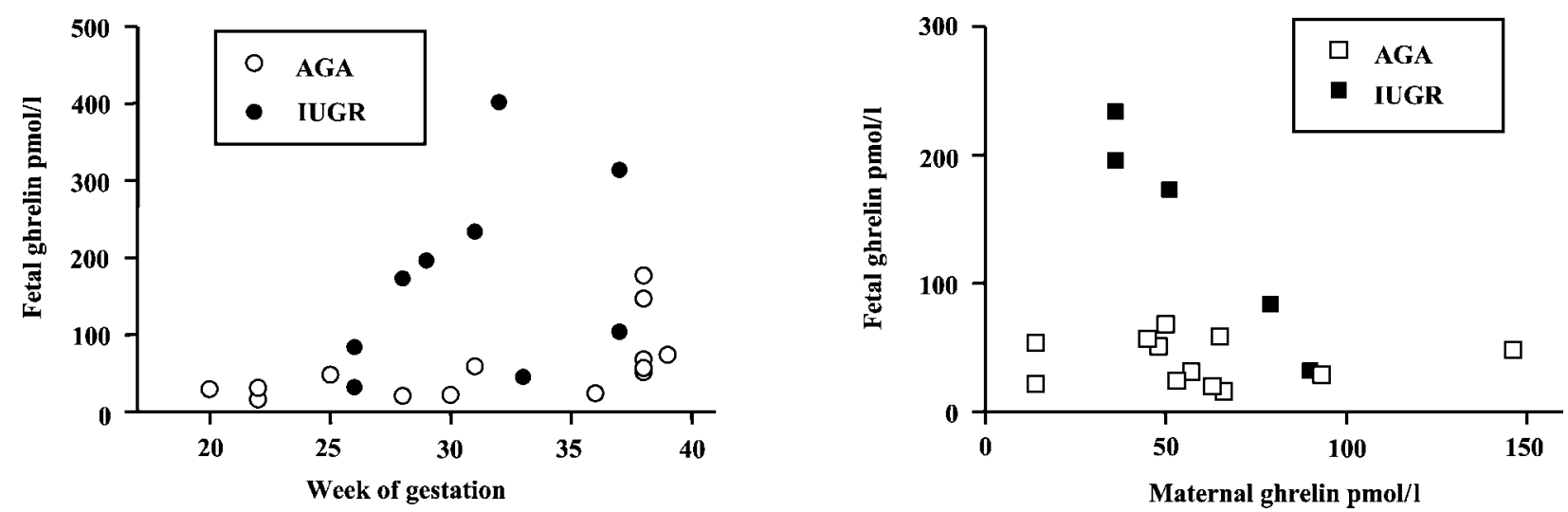

Figure 1 Circulating levels of ghrelin measured in 16 AGA and nine IUGR fetuses during gestation. No positive correlation was found with gestational age $\left(r^{2}=0.04, P=\mathrm{NS}\right)$ (left graph) and no correlation was observed with maternal ghrelin (right graph) in 17 blood samples from normal and IUGR pregnancies collected simultaneously $\left(r^{2}=0.06, P=\mathrm{NS}\right)$.

16-402 pmol/l) without difference by gender and correlation with gestational age (Fig. 1). No positive correlation between maternal $(65 \pm 35 \mathrm{pmol} / \mathrm{l})$ and fetal ghrelin concentrations was observed (Fig. 1). Moreover, by measuring ghrelin levels in both umbilical artery $(95 \pm 95 \mathrm{pmol} / \mathrm{l})$ and vein $(94 \pm 72 \mathrm{pmol} / \mathrm{l})$ from three term AGA fetuses no significant veno-arterial difference was found. Plasma ghrelin levels observed in IUGR fetuses were significantly higher than those found in AGA fetuses (176 \pm 125 vs $58 \pm 44 \mathrm{pmol} / \mathrm{l}$; $P<0.005$; Table 2). Accordingly, in 13 samples obtained at birth (eight from AGA fetuses, five from IUGR fetuses) ghrelin concentrations correlated negatively with birth weight (Fig. 2).

Plasma GH concentrations $(18.4 \pm 14.3 \mu \mathrm{g} / \mathrm{l})$ did not show significant differences between sexes and correlated negatively with gestational age (Fig. 3). Circulating GH levels were significantly higher in IUGR fetuses than in AGA fetuses $(29.8 \pm 6.1$ vs $10.6 \pm 2.1 \mu \mathrm{g} / \mathrm{l} ; \quad P<0.05$ ) (Table 2) and correlated negatively with birth weight (Fig. 2). Plasma leptin concentrations were higher in female than male AGA and IUGR fetuses $(10.7 \pm 12.1$ vs $2.5 \pm 2.2 \mathrm{ng} / \mathrm{ml}$; $P<0.05)$ and positively correlated with gestational age (Fig. 3). Moreover, after 34 weeks of gestation, leptin levels were lower in IUGR fetuses than in AGA fetuses $(2.9 \pm 1.7$ vs $11.7 \pm 11.2 \mathrm{ng} / \mathrm{ml})$, although the

Table 2 Circulating levels of ghrelin, GH, leptin and cortisol in AGA and IUGR fetuses. All data are presented as means \pm S.D. $n=$ number of cases.

\begin{tabular}{|c|c|c|c|c|}
\hline & $\begin{array}{l}\text { Ghrelin } \\
(\mathrm{pmol} / \mathrm{l})\end{array}$ & $\begin{array}{l}\text { GH } \\
(\mu \mathrm{g} / \mathrm{l})\end{array}$ & $\begin{array}{l}\text { Leptin } \\
\text { (ng/ml) }\end{array}$ & $\begin{array}{l}\text { Cortisol } \\
(\mathrm{nmol} / \mathrm{l})\end{array}$ \\
\hline AGA fetuses & $\begin{array}{l}58 \pm 44 \\
n=16\end{array}$ & $\begin{array}{r}10.6 \pm 2 \\
n=8\end{array}$ & $\begin{array}{c}8.1 \pm 10.5 \\
n=15\end{array}$ & $\begin{array}{r}126 \pm 48 \\
n=11\end{array}$ \\
\hline IUGR fetuses & $\begin{array}{c}176 \pm 25^{\star \star} \\
n=9\end{array}$ & $\begin{array}{c}29.8 \pm 6.1^{*} \\
n=6\end{array}$ & $\begin{array}{c}2.3 \pm 2.4 \\
n=9\end{array}$ & $\begin{array}{c}175 \pm 40^{*} \\
n=7\end{array}$ \\
\hline
\end{tabular}

${ }^{\star} P<0.05$ vs $A G A,{ }^{*} P<0.005$ vs AGA. difference did not reach significance (Table 2). A positive correlation between leptin levels and birth weight was observed (Fig. 2). Plasma cortisol levels, ranging from 62 to $230 \mathrm{nmol} / \mathrm{l}$ and increasing with gestational age (Fig. 3), were significantly higher in IUGR fetuses than in AGA fetuses $(175 \pm 40$ vs $126 \pm 48 \mathrm{nmol} / \mathrm{l}$; $P<0.05$; Table 2). No significant correlation between fetal ghrelin and $\mathrm{GH}$, leptin or cortisol levels was found.

\section{Discussion}

This study demonstrates for the first time that ghrelin is present in the human fetal circulation during gestation. Admittedly, since the commercially available RIA kit detected both octanoylated bioactive and non-octanoylated bio-inactive ghrelin, total ghrelin may not strictly reflect the biologically active peptide. Ghrelin was clearly detectable in the umbilical venous blood in fetuses from 20 weeks to term, without sex-related differences. No significant variation in ghrelin levels was observed throughout the gestation, though data did not cover each gestation week due to the low number of pregnancies requiring cordocentesis.

As far as the origin of the peptide is concerned, the recent demonstration that ghrelin mRNA and protein are expressed in the placenta makes this organ a good source of ghrelin production and release into the fetal circulation (16). However, the present study provided evidence for a fetal origin of the peptide since neither significant umbilical veno-arterial difference of ghrelin levels in term fetuses nor correlation between maternal and fetal plasma levels were observed. Accordingly, an origin from fetal tissues may be suggested by the observation that the peptide seems to be almost absent in the placenta during the last trimester (16) while ghrelin persisted in the fetal circulation until term.

Intrauterine growth restriction was associated with a significant increase of plasma ghrelin levels, although values recorded in IUGR and AGA fetuses showed 

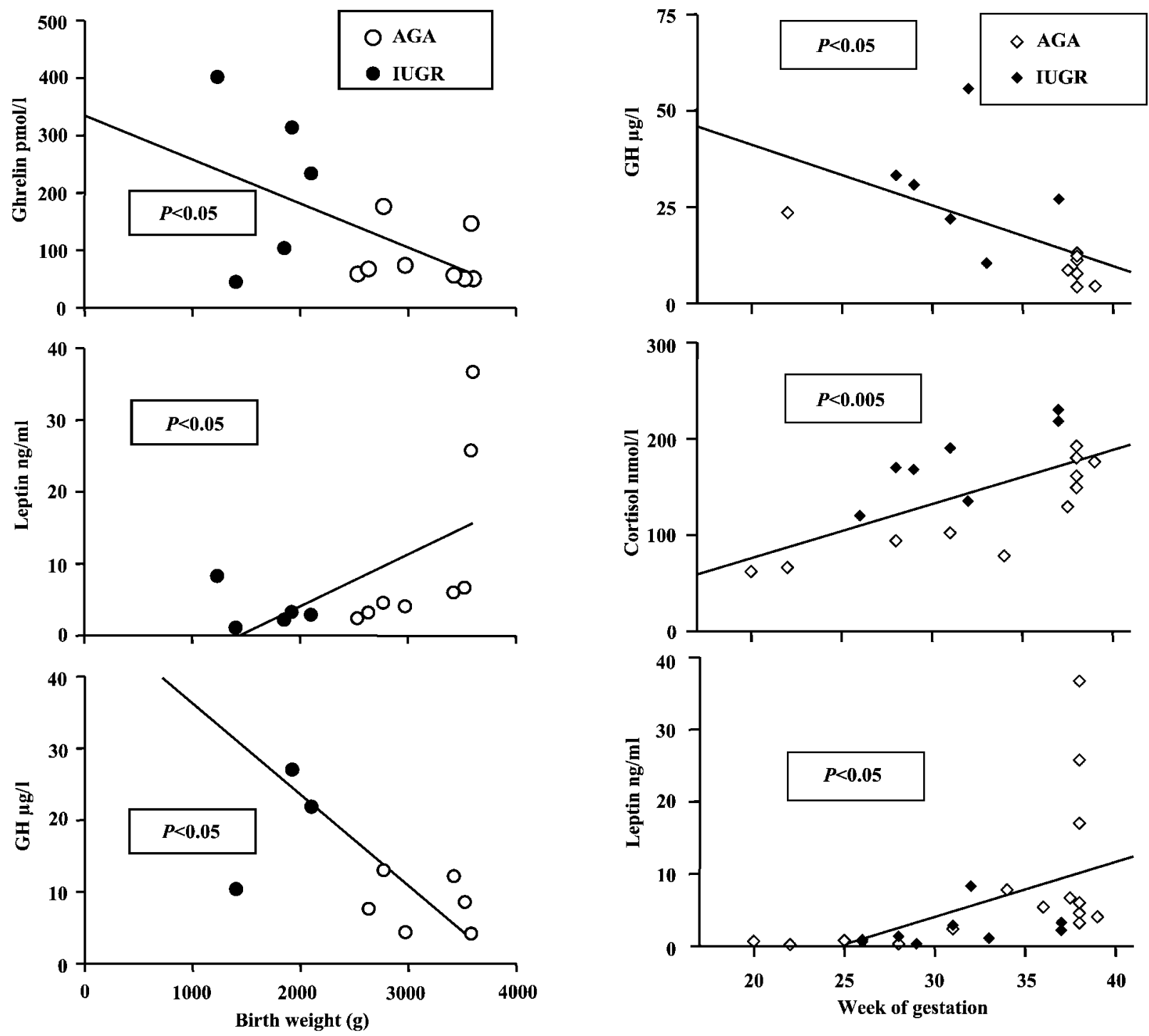

Figure 2 Negative correlations between birth weight and ghrelin and GH levels in AGA and IUGR neonates $(P<0.05)$. In the same fetuses a positive correlation was observed between birth weight and leptin levels $(P<0.05)$.

some overlapping. This observation is in agreement with a recent study in which ghrelin was detected in cord blood of full-term neonates and correlated negatively with birth weight (17). A similar correlation was also found at birth in the present study. Several mechanisms may be responsible for the high ghrelin levels observed in IUGR fetuses. First, this pattern of secretion may be an additional component of the altered somatotrophic axis observed in growthrestricted fetuses. Indeed, as previously described, plasma GH levels in cord blood were higher in IUGR fetuses than in normal fetuses and negatively correlated with birth weight, probably as a result of the reduced IGF-I levels present in this pathological condition

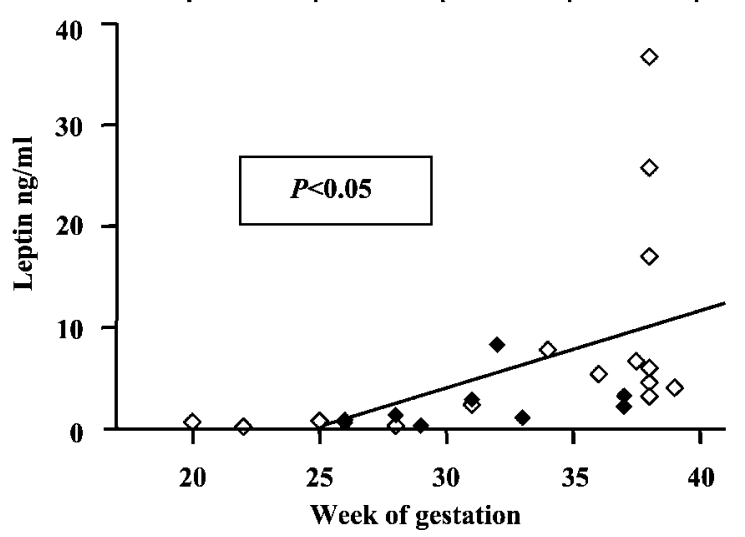

Figure 3 Circulating levels of $\mathrm{GH}$, cortisol and leptin in AGA and IUGR fetuses. In both groups, GH levels correlated negatively with gestational age $(P<0.05)$ while cortisol and leptin levels correlated positively with gestational age $(P<0.005$ and $P<0.05$ respectively). In IUGR fetuses, both $\mathrm{GH}$ and cortisol levels were significantly higher than in AGA fetuses $(P<0.05)$, while leptin concentrations were not significantly lower in IUGR fetuses than in AGA fetuses after 34 weeks of gestation (see Table 2).

$(22,23)$. Therefore, it is likely that low IGF-I associated with intrauterine growth restriction may induce ghrelin overproduction, although the feedback mechanisms regulating ghrelin secretion are still poorly understood. Alternatively, the increased levels of ghrelin observed in IUGR fetuses may be related to the role of this peptide in energy balance. Indeed, plasma ghrelin levels have been reported to be increased by fasting and anorexia and decreased by acute or chronic states of positive energy balance (11-15). Accordingly, ghrelin appears 
to be negatively correlated with body mass index, body fat mass and leptin levels (6). A similar pattern was also observed in full-term neonates who presented a positive correlation between leptin and birth weight, in agreement with previous reports $(24,25)$. Therefore, it is conceivable that high ghrelin levels may represent a 'hunger signal' in IUGR fetuses, which showed low levels of the 'satiety signal' leptin. Finally, since ghrelin has been demonstrated to increase ACTH and cortisol secretion in humans and rodents, a possible role of ghrelin in the activation of the hypothalamic-pituitary-adrenal axis in fetal distress could be envisaged (8). Accordingly, plasma cortisol concentrations were found to be higher in IUGR fetuses than in normally grown fetuses. Previous studies suggested that the increases in circulating cortisol may play an important role in the adaptation of the fetal cardiovascular system to intrauterine growth restriction (26). Taken together these data indicate that intrauterine growth restriction is associated with several hormonal changes that, although not strictly correlated, include the increase in ghrelin levels as well as the previously reported changes in GH, leptin and cortisol secretion.

In conclusion, our data indicate that ghrelin is present in fetal plasma from 20 weeks to term. Although the placenta is likely to be an important source of ghrelin, fetal production is consistent with the absence of differences between umbilical venous and arterial values together with the lack of correlation between maternal and fetal ghrelin levels. Moreover, the high levels of ghrelin observed in fetuses with intrauterine growth restriction suggest a possible role of this peptide during intrauterine life, especially in determining adaptations of the fetus to an adverse intrauterine environment.

\section{Acknowledgements}

This study was partially supported by grants Ricerca Corrente, Ospedale Maggiore IRCCS (Milan) and MURST (Rome).

\section{References}

1 Kojima M, Hosoda H, Date Y, Nakazato M, Matsuo H \& Kangawa K. Ghrelin is a growth hormone-releasing acylated peptide from stomach. Nature $1999 \mathbf{4 0 2} 656-660$.

2 Peino R, Baldelli R, Rodriguez-Garcia J, Rodriguez-Segade S, Kojima M, Kangawa K et al. Ghrelin-induced growth hormone secretion in humans. European Journal of Endocrinology 2000 143 R $11-\mathrm{R} 14$.

3 Dieguez C \& Casanueva FF. Ghrelin: a step forward in the understanding of somatotroph cell function and growth regulation. European Journal of Endocrinology $2000 \mathbf{1 4 2}$ 413-417.

4 Bowers CY. Unnatural growth hormone-releasing peptide begets natural ghrelin. Journal of Clinical Endocrinology and Metabolism 200186 1464-1469.

5 Kojima M, Hosoda H, Matsuo H \& Kangawa K. Ghrelin: discovery of the natural endogenous ligand for the growth hormone secretagogue receptor. Trends in Endocrinology and Metabolism $200112118-122$.

6 Horvath TL, Diano S, Sotonyi P, Heiman M \& Tschop M. Minireview: Ghrelin and the regulation of energy balance - a hypothalamic perspective. Endocrinology $20011424163-4169$.

7 Seoane LM, Tovar S, Baldelli R, Arvat E, Ghigo E, Casanueva FF et al. Ghrelin elicits a marked stimulatory effect on GH secretion in freely-moving rats. European Journal of Endocrinology 2000 143 R 7-R9.

8 Arvat E, Maccario M, Di Vito L, Broglio F, Benso A, Gottero C et al. Endocrine activities of ghrelin, a natural growth hormone secretagogue (GHS) in humans: comparison and interaction with hexarelin, a nonnatural peptidyl GHS, and GH-releasing hormone. Journal of Clinical Endocrinology and Metabolism 2001 86 1169-1174.

9 Hataya Y, Akamizu T, Takaya K, Kanamoto N, Ariyasu H, Saijo M et al. A low dose of ghrelin stimulates growth hormone (GH) release synergistically with GH-releasing hormone in humans. Journal of Clinical Endocrinology and Metabolism $2001 \mathbf{8 6}$ $4552-4555$.

10 Tschop M, Smiley D \& Heiman ML. Ghrelin induces adiposity in rodents. Nature $2000 \mathbf{4 0 7} 908-913$.

11 Wren AM, Seal LJ, Cohen MA, Brynes AE, Frost GS, Murphy KG et al. Ghrelin enhances appetite and increases food intake in humans. Journal of Clinical Endocrinology and Metabolism 2001 $865992-5995$.

12 Tshop M, Weyer C, Tataranni PA, Devanarayan V, Revussin E \& Heiman ML. Circulating ghrelin levels are decreased in human obesity. Diabetes $200150707-709$.

13 Ariyasu H, Takaya K, Tagami T, Ogawa Y, Hosoda K, Akamizu T et al. Stomach is a major source of circulating ghrelin, and feeding state determines plasma ghrelin-like immunoreactivity levels. Journal of Clinical Endocrinology and Metabolism $2001 \mathbf{8 6}$ $4753-4758$.

14 Otto B, Cuntz U, Fruehauf E, Wawarta R, Folwaczny C, Riepl RL et al. Weight gain decreases elevated plasma ghrelin concentrations of patients with anorexia nervosa. European Journal of Endocrinology $2001 \mathbf{1 4 5}$ R5-R9.

15 Nagaya N, Uematsu M, Kojima M, Date Y, Nakazato M, Okumura $\mathrm{H}$ et al. Elevated circulating level of ghrelin in cachexia associated with chronic heart failure: relationships between ghrelin and anabolic/catabolic factors. Circulation $2001 \mathbf{1 0 4}$ 2034-2038.

16 Gualillo O, Caminos JE, Blanco M, Garcìa-Caballero T, Kojima M, Kangawa K et al. Ghrelin, a novel placental-derived hormone. Endocrinology 2001142 788-794.

17 Chanoine JP, Yeung LPK, Wong ACK \& Birmingham CL. Immunoreactive ghrelin in human cord blood: relation to anthropometry, leptin, and growth hormone. Journal of Pediatric Gastroenterology and Nutrition 200235 282-286.

18 Parazzini F, Cortinovis I, Bortolus R \& Fedele L. Standards of birth weight in Italy. Annali di Ostetricia e Ginecologia e Medicina Perinatale 1991 CXII 203-246.

19 Todros T, Ferrazzi E, Groli C, Nicolini U, Parodi L, Pavoni M et al. Fitting growth curves to head and abdomen measurements of the fetus: a multicentric study. Journal of Clinical Ultrasound 198715 95-105.

20 Pardi G, Cetin I, Marconi AM, Lanfranchi A, Bozzetti P, Ferrazzi E et al. Diagnostic value of blood sampling in fetuses with growth retardation. New England Journal of Medicine $1993 \mathbf{3 2 8}$ 692-696.

21 Cappiello V, Ronchi C, Morpurgo PS, Epaminonda P, Arosio M, Beck-Peccoz P et al. Circulating ghrelin levels in basal conditions and during glucose tolerance test in acromegalic patients. European Journal of Endocrinology 2002 147 189-194.

22 Gluckman PD, Grumbach MM \& Kaplan SL. The neuroendocrine regulation and function of growth hormone and prolactin in the mammalian fetus. Endocrine Reviews 19812 363-395.

23 Arosio M, Cortelazzi D, Persani L, Palmieri E, Casati G, Baggiani AM et al. Circulating levels of growth hormone, 


\section{D Cortelazzi and others}

insulin-like growth factor-I and prolactin in normal, growth retarded and anencephalic human fetuses. Journal of Endocrinological Investigation 199518 346-353.

24 Koistinen HA, Koivisto VA, Andersson S, Karonen SL, Kontula K, Oksanen L et al. Leptin concentration in cord blood correlates with intrauterine growth. Journal of Clinical Endocrinology and Metabolism 199782 3328-3330.

25 Cetin I, Morpurgo PS, Radaelli T, Taricco E, Cortelazzi D, Bellotti M et al. Fetal plasma leptin concentrations: relationship with
EUROPEAN JOURNAL OF ENDOCRINOLOGY (2003) 149

different intrauterine growth pattern from 19 weeks to term. Pediatric Research 200048 646-651.

26 McMillen IC, Adams MB, Ross TJ, Coulter CL, Simonetta G, Owens JA et al. Fetal growth restriction: adaptations and consequences. Reproduction 2001122 195-204.

Received 25 November 2002

Accepted 5 May 2003 